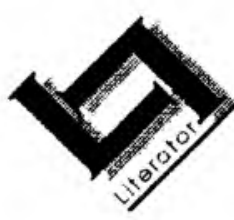

\title{
KWU-werkersklasdramas ${ }^{1}$ in Afrikaans (ca. 1930 - ca. 1950)
}

\author{
J.L. Coetser \\ Departement Afrikaans \\ Universiteit van Suid-Afrika \\ PRETORIA \\ E-pos: coetsi|@alpha.unisa.ac.za
}

\begin{abstract}
GWU working class theatre in Afrikaans (ca. 1930 - ca. 1950)

In 1984 Elsabé Brink drew attention to plays, prose and poetry written between 1930 and 1950 in Afrikaans by members of the Garment Workers' Union (GWU). Scholars such as Stander and Willemse (1992), Van Niekerk (1996) and Van Wyk $(1995,1997)$ have also referred to GWU plays. Apart from these overviews, GWU plays as such have not yet received the attention they deserve. This article presents a revaluation, initially by providing an overview of their contents, followed by an examination of cultural, economic and political influences. It is argued that retrospectively - the GWU plays reflected a unique cultural specificity from the framework established by Sitas (1986) for more contemporary working class theatre.
\end{abstract}

\section{Inleiding en doelwitstelling}

N.P. van Wyk Louw (1939:16) het reeds in 1936 in 'n toespraak op Stellenbosch na die moontlike bestaan van werkersliteratuur in Afrikaans verwys, met ander woorde na tekste waarin 'n werkerstem voorkom. Dit was in dieselfde jaar dat 'n berig oor die teaterbedrywighede van lede van die Klerewerkersunie (KWU) in die Klerewerker, orgaan van die KWU, verskyn het (Anon., 1936).

1 Die KWU-dramaturge het egter na hulself as die "werkendeklas" verwys, en hul werk benoem as "werkendeklasdramas". 
$\mathrm{Na} 1980$ het die literatuur van die klerewerkers gaandeweg die aandag van ondersoekers begin trek. In hierdie verband bied Elsabé Brink (1984, 1986, 1989) oorsigte van hul prosa, poësie en dramas, en die wyse waarop die klerewerkers betrokke was by die ideologiese konstruksie van die begrip volksmoeder (Brink, 1990). Lourens (1997) gee oorsigtelik aandag aan hul prosageskrifte, terwyl Stander en Willemse (1992), Van Niekerk (1996) en Van Wyk $(1995,1997)$ hul skryfwerk tesame met dié van ander outeurs betrek.

Daar was gevolglik nog nie 'n ondersoek van skryfwerk deur lede van die KWU wat uitsluitlik op hul dramas konsentreer nie. Daarom is die doel met hierdie bespreking om 'n herevaluering van die klerewerkers se dramaproduksie te lewer, eers deur besonderhede oor hul tekste te gee en daama deur hulle dramas binne die konteks van hul werkersgeskiedenis te plaas. Die vraag wat ondersoek word, is of daar ooreenkomste bestaan tussen KWU-dramas en ander werkersklasdramas in die algemeen. Met ander woorde, sluit KWU-tekste, retrospektief beskou, by ' $n$ bestaande verwysingsraanwerk aan, en, indien wel, wat is die aard van dié aansluiting?

\section{Besonderhede oor KWU-tekste}

'n Bespreking van dié dramatekste soos hulle in argivale vorm bestaan', lewer 'n aantal literêr-historiese probleme op wat verband hou met die feit dat hulle eerstens vir opvoering geskryf is. Didaskaliese gegewens, soos die naam van die dramaturg of die datum en plek van die eerste opvoering, ontbreek dikwels. Op grond van die oorwegings gaan hierdie bespreking van die volgende indeling uit:

- tekste waarin geen ontstaans- of opvoeringsdatums voorkom nie, en datums gerekonstrueer moet word op grond van verbande met werklike gebeurtenisse;

- tekste waarin geen ontstaans- of opvoeringsdatums in die neweteks voorkom nie, maar waarin datumverwysings in die hoofteks verskyn;

2 Die dramatekste deur lede van die Klerewerkersunie (KWU) kom uit die Argief van die Klerewerkersunie, wat ' $n$ onderdeel vorm van die Archives of the Church of the Province of Southem Africa. Hierdie versameling word tans in dic afdeling Historical and Literary Papers van die William Cullen Biblioteek van die Universiteit van die Witwatersrand bewaar. Dit is deur Marcelle Jacobson en Anna M. Cunningham (1980) ontsluit. Ek is dank verskuldig aan Elsabé Brink vir haar beskikbaarstelling van ander tekste waarvan ek bewus was, maar nie in die hande kon kry nie. In hierdie bespreking maak ek van 'n eie verwysingstelsel gebruik, waarin die verwysings wat op argivale dokumente betrekking het in ' $n$ "Lys van argivale bronne" aan die einde verklaar word Afdrukke van dié argivale materiaal is in my besit. Die "Lys van argivale bronne" sluit nie materiaal in wat in die KWU-tydskrif, die Klerewerker, gepubliseer is nie. 
- tekste waarvoor ontstaans- of opvoeringsdatums in die Klerewerker of 'n ander bron beskikbaar of by benadering beskikbaar is.

Slegs een voorbeeld van 'n teks waarin 'n datumverwysing in die hoofteks voorkom, kon gevind word, naamlik Labour beats the drum (ArKW 42.2.3 en 48). Omdat dit op 1 Mei 1954 opgevoer is en dus buite die afbakening van die artikel val, verwys ek nie verder daarna nie.

\subsection{Geen ontstaans- of opvoeringsdatum}

Johanna Cornelius se Drie spioene (ArKW 42.2.7) is 'n voorbeeld van so 'n teks. Die handelingsverloop stem ooreen met 'n voorval wat in 1936 plaasgevind het. 'n Jonger aantekening as die oorspronklike dokument in 'n ongeïdentifiseerde handskrif, wat aan die argivale teks geheg is, beskryf die insident soos volg:

In 1936 Joanna Cornelius and two other GWU organisers were sent to Cape Town to get jobs in Cape clothing factories to help with GWU's organising campaign there [...] This play seems to be aimed at informing Transvaal members of the Cape campaign and winning their support for the energy, money, etc. spent by TvlGWU in the Cape.

Minnie Britz (1941:9), 'n Kaapstadse werker, bevestig hierdie gebeure in 'n gediggie wat sy "Kaapstad ontwaak" noem. Drie spioene het dus waarskynlik tussen 1936 en 1941 ontstaan.

Die aantekening skep die indruk dat die stuk nie in die eerste plek geskryf is om opgevoer te word nie, alhoewel opvoering nie uitgesluit kan word nie. Dié indruk word versterk deur die feit dat die KWU hul kultuurafdeling, met Maggie Kruger as sameroeper, eers in 1940 gestig het (Anon., 1940). Dit sluit nie die moontlikheid van dramabedrywighede voor 1940 uit nie, maar versterk wel die afleiding dat die voortsetting van literêr-dramatiese bedrywighede aanvanklik aan die entoesiasme van indiwidue gekoppel is.

The trial of the 22 (ArKW 42.2 .5 en 49) behandel Jim en Mary se ekonomiese lyding, as 'n aanloop tot die werklike verhoor van Rose de Freitas en een en twintig werkers van Black \& Company (Kaapstad) wat in 1936 onwettig gestaak het (Sachs, 1957:234). Die neweteks aan die begin van die (jongste) ArKW 42.2.5-weergawe verduidelik dat die handeling tussen Februarie en Maart 1936 in Kaapstad afspeel. Kenmerkend van The trial of the 22 is die gelyktydige gebruik van Afrikaans en Engels en dat die teks ook as 'n variant voorkom.

Die lede van die KWU was vanaf die vakbond se ontstaan in 1929/1930 uit die manlik oorheersde Witwatersrand Tailors Association, hoofsaaklik jong Afrikaanssprekende vroue. In 1938 was ongeveer $78 \%$ van die lede wit en Afrikaanssprekend, maar teen 1953 was dié persentasie slegs 40 (Jacobson \& 
Cunningham, 1980:xi). Dit wil dus voorkom of die oorheersende gebruik van Engels in The trial of the 22 'n vroeë aanduiding was van die latere dominansie van Engels in die KWU en van die teenstand wat die Unie sou bied teen pogings van aanhangers van Afrikanemasionalisme om lede, onder andere op grond van rasse-oorwegings, onder die Nasionaliste se invloed te bring. Die toename van niewitlede het tot rassespanning gelei (Witz, 1988), al het vakbondleiers hul bes gedoen om 'n gees van verdraagsaamheid en nierassigheid te skep.

Teen hierdie agtergrond is dit opvallend dat die jongste weergawe van The trial of the 22 (ArKW 42.2.5) verskeie wysigings bevat om dit in ooreenstemming met 'n KWU-beleid van nierassigheid te bring. In die oudste weergawe (ArKW 49), byvoorbeeld, is Mary se buurvrou 'n blanke klerewerkster met die naam Hettie. In die jongste weergawe word sy Asa, en stel die personelys dit dat sy 'n "Malay Garment Worker, middle-aged, class-conscious" is. Verder verwys Jim na 'n dokwerkervoorman met behulp van rassemerkers: "The white man gets all the jobs. He doesn't need to bribe a foreman. The Government looks after him alright". Hierdie verwysing kom nie in die oudste teks voor nie. Tydens die verhoor waaraan die teks sy titel ontleen, vra die aanklaer aan aangeklaagde nommer 1: "Why do you, a white girl, associate with these blacks?" Sy antwoord: "Yes, you try this one on me. [...] These coloured workers are no worse than I am, we are all slaves, and, (shouts) we don't want to be slaves any more!"

\subsection{Ontstaans- of opvoeringsdatums in ' $n$ bron}

Van 'n groot groep klerewerkerstekste is die ontstaans- of opvoeringsdatum bekend of by benadering bekend, omdat dit in die Klerewerker of in ' $n$ ander bron voorkom.

Die ontstaansdatum van Hester Cornelius se Eendrag (ArKW 54) is op grond van die beskikbare argivale materiaal slegs by benadering bepaalbaar. Dié drama dra die boodskap oor dat, indien werkers saamstaan, hul die baasklas of kapitaliste kan oorwin. In die teks word dit bekend dat sommige van die klerewerkers afgedank gaan word omdat daar nie genoeg werk is nie. Bessie word onregmatig ontslaan, maar die fabriekbaas, Levine, stel haar weer aan as die res van die werkers dreig om te staak. Die Klerewerker bevat 'n verslag van 'n opvoering in 1941 (Anon., 1941c). Op grond van ooreenkomste met die handelingsverloop in Drie spioene (ArKW 42.2.7), waarvan die inhoud verband hou met 'n gebeurtenis wat uit 1936 dateer, bestaan die moontlikheid dat albei tekste tussen 1936 en 1941 ontstaan het.

In 1939 verskyn in die Klerewerker twee kort agitasie-en-propaganda-stukke (agitprop), wat blykbaar nie vir opvoering geskryf is nie. Die redakteur moes van mening gewees het dat die propagandistiese aard van die inhoud die beste gedien kan word deur van 'n dramavorm gebruik te maak. Mary Myburgh en Maud 
Goldwyer (1939) se 'n Staaltjie uit die lewe van twee klerewerkers is 'n dialoog met die doel om nuwe lede vir die KWU te werf. Op grond van die ooreenstemming tussen die name van die outeurs en die personasies, kan ons aanvaar dat dié stuk outobiografies en dus 'n egodokument is.

In Hou op met die oorlogsbasuin! (Anon., 1939b) spreek die onbekende skrywer in verse teenkanting uit teen die naderende oorlog. Dié teks het 'n verbasende gesofistikeerdheid, ook wat die struktuur betref. Daar is 'n duidelike en emosionele opbou na 'n klimaks en die gebruik van 'n karakter in die gehoor. Ook die inhoud is vir die tyd ongewoon omdat dit 'n breër konteks, naamlik die Eerste Wêreldoorlog en Europa/Frankryk, as bloot die Suid-Afrikaanse betrek. In hierdie opsig herinner die teks aan Uys Krige se werk, maar dit is duidelik vanuit 'n vroulike, KWU-werkersperspektief geskryf.

1941 was ' $n$ besonder produktiewe jaar, want die KWU voer vier werkersklasdramas op en 'n vyfde kort stuk verskyn in die Klerewerker. Die eerste aanbieding (Anon., 1941a) was van Hester en Johanna Cornelius se Slavin van Suid-Afrika (ArKW 57). Jessie McPherson (1941:2) beskryf die opvoering van Slavin van Suid-Afrika soos volg:

Op die 7de Maart was Internasionale Vrouedag vir die eerste keer in SuidAfrika gevier. Omtrent 500 werkende vrouens en 'n aantal mans was teenwoordig in die H.O.D.-saal waar toesprake, resitasies, liedere en selfs 'n toneelstuk: 'Slavin van Suid-Afrika', gelewer was [...].

Die stuk bestaan uit 'n aantal kort tonele waarin voorvalle uit die gewone en werkerslewe van vroue voorgestel word.

Broers (ArKW 42.2.6) is op 1 Mei 1941 in die Arbeidsaal opgevoer, tesame met die Engelse eenakter The great philanthropist (Cornelius, 1941:11). Dieselfde Engelse stuk is later in die jaar tesame met die Afrikaanse werkersklasdrama Unieseël in Kingston House, Pritchardstraat, Johannesburg op versoek van die Lekkergoedwerkers opgevoer (Cornelius, 1941:11). Broers handel oor die geskille tussen die broers Jan, 'n stakende werker, en Hans de Wet, 'n polisieman. Jan word tydens 'n polisiestormloop erg aangerand, met die gevolg dat Hans hom by sy klas, die werkersklas, skaar.

Hester Cornelius (1942a, 1942b) se Die offerande is op 10 November 1941 te Mainstraat 128, Johannesburg en op 17 November 1941 in die Germistonse stadsaal deur die Germiston-afdeling van die KWU se Volksteater opgevoer (Anon., 194lb). Dit is die enigste lang KWU-teks wat in die Klerewerker gepubliseer is. In die drama verloor oom Kalie sy plaas as gevolg van skuld. Die buurman, oom Hans, sou sy skuld delg indien Lettie, sy dogter, bereid was om met hom te trou. Sy trou egter met Danie, en die gesin beland op 'n delwery waar hul seun Jan as gevolg van Hans se toedoen op aanklag van onwettige 
diamanthandel in hegtenis geneem word. Tussendeur stel Jan se vrou, Werda, die werkers se saak. Werda spreek haar onder andere gunstig uit oor die Sowjetunie se stelsel van gemeenskapsplase.

Al word Die offerande in die inleiding 'n "Afrikaanse werkendeklasdrama" genoem, is daarin nie veel sprake van die uitbeelding van die werkerslewe nie. Die voorstelling van 'n werkersbestaan op die delwery volg eers aan die einde van die teks en verteenwoordig daardeur 'n ideologiese breuk met ander KWUwerkersklasdramas. Danie, Lettie se man, dra wel die werkers se ideale vroeg in die teks in, maar sy invalshoek is duideliker polities as slegs werkersgerig. Die kollig val op die boerelewe, waardeur die teks eerder by die literêre sisteem aansluit as dat dit die sisteem ondermyn. Hierdie aansluiting geld in die besonder ten opsigte van die plaasroman in Afrikaans. Uitgaande van Van Coller (1995:2526) se tipologie, is daar in Die offerande ook sprake van singewende, feodale, mitiese, onvervreembare, patriargale, historiese, religieuse, maar veral idilliese ruimte. Laasgenoemde blyk onder andere uit Kalie-hulle se vergeefse hunkering terug plaas toe. Hul vroeëre, idilliese bestaan is onherwinbaar verby; 'n nuwe werkersklasbestaan het vir hulle aangebreek.

Soos Die offerande verskyn in 1941 ook in die Klerewerker die kort stuk, Kersfees vir die armes (Anon., 1941d). Dit is die voorstelling van 'n besoek van Kersvader aan 'n arm werkersgesin. Dit blyk egter dat Kersvader die hoof van die huis is en dat hy al die geskenke en die kostuum gesteel het. Nog 'n kort teks verskyn in 1947 in die Klerewerker, naamlik Die plig van 'n fabriekverteenwoordiger (Anon., 1947). Die teks is 'n voorbeeld van die KWU-bestuur se gebruik van die dramavorm om klerewerkers oor 'n saak in te lig, hier hoe hulle van hul fabrieksverteenwoordigers gebruik kan maak.

$\mathrm{Na} 1941$ het die dramabedrywighede van die KWU baie afgeneem, onder andere as gevolg van politieke druk deur die Nasionale Party en na 1948 as gevolg van druk deur die Nasionale Party as nuwe regerende party (Brink, 1986; Sachs, 1957; Witz, 1984). Verder is leiersfigure in die KWU mettertyd in die bedryf bevorder en was hulle daarom nie meer direk by werkersbelange betrokke nie. 'n Derde verklaring is dat al minder blanke Afrikaanssprekende vroue tot die bedryf toegetree het namate die regering al meer werkgeleenthede vir blanke Afrikaanssprekendes in die staatsdiens geskep het.

Dit is teen hierdie agtergrond dat Hester Cornelius in die vyftigerjare Tant Mieta, die Cruet Stand en die Klerewerkersunie van S.A. (ArKW 56) skryf. Die titel is later verander na Bure moeilikhede (ArKW 42.2.2). In die teks kom 'n buurvrou se kind om sout te leen. As teenprestasie vereis tant Mieta dat die lener haar "cruet stand" die komende Sondag aan haar sal leen. Haar dogter wil Johannesburg toe gaan om 'n klerewerkster te word. Die stuk is 'n klug, waarvan die slotsin 'n aanduiding gee van die humor wat daarin voorkom: "Antie my Ma 
sê haar een kroet stên het sy aan - en die ander een is in die was". Tant Mieta, die Cruet Stand en die Klerewerkersunie van S.A. was waarskynlik 'n poging om blanke Afrikaanssprekendes na die klerebedryf te lok. Die klugtige aard daarvan moes aan die gehoor 'n aanduiding gee van hoe aangenaam dit sou wees om 'n klerewerker te word.

Op grond van voorgaande oorsig en in navolging van Gready (1994:163) is dit gevolglik moontlik om te beweer dat KWU-werkersklasdramas outobiografies van aard was en dat dié aard 'n rol gespeel het by die totstandkoming van 'n eiesoortige Afrikaanse werkersklasidentiteit. Gready (1994:175) se beskrywing van die inhoud van Natalse werkersklastekste uit die jare tagtig is inderdaad op die KWU-dramas van toepassing:

The content of worker theatre drew largely on a troika of seminal formative features: the reflection of worker life experiences; the centrality of work and the production process, and the political projection and attempted cultural realisation of a vision of the future.

Spesifieke "seminal formative features" wat by KWU-dramas 'n rol gespeel het, sluit dus ekonomiese, politieke en kulturele faktore in as voorstellings van 'n Afrikaanse werkersklasgeskiedenis.

\section{Werkersgeskiedenis}

Een van die vroegste rigtingwysers na die bestaan van 'n werkersgeskiedenis onder die klerewerkers hou met die beplande opvoering van I.G. Horak (1925) se drama Sannie Pienaar verband. Dié aanduiding het verskyn in 'n berig (Anon., 1936:7) wat uit November 1936 dateer:

Ons hoor dat die Klerewerkers van Germiston en die Spoorwerkers besig is om 'n Afrikaanse Drama te oefen; die doel is om Afrikaanse kultuur op te bou. 'Sannie Pienaar', die toneelstuk, handel oor die Vryheidsoorlog van 1899 , en dit wys ons die tradiesies van ons ou volk. Ons is baie bly om te sien dat die Klerewerkers en Spoorwegwerkers so 'n verenigde front gestig het; ons hoop hulle alle sukses toe, en hoop dat Johannesburg ook hulle voorbeeld sal volg.

Alhoewel Isaac Gerhardus Horak (1925) se Sannie Pienaar: 'n drama uit die Twede Vryheidsoorlog (Op waarheid gegrond) nie 'n KWU-werkersklasdrama is nie, is die klere- en spoorwegwerkers se keuse daarvan veelbetekenend. Aangesien die drama in die omgewing van 1937, en die eerste KWU-werkersklasdrama tussen 1936 en 1941, opgevoer is, moet die waarde van Sannie Pienaar beoordeel word teen die agtergrond daarvan dat die opvoering aan die begin van die verskyning van 'n reeks KWU-dramas plaasgevind het. Die aard van die stuk moes die KWU-bestuur tot 'n besef gebring het van die waarde wat dramas kan 
hê om 'n bewuste kulturele en werkersidentiteit onder lede te vestig. Daarvan getuig die goedkeurende verwysing na die "verenigde front" wat die klere- en spoorwegwerkers rondom 'n kulturele gebeurtenis tot stand gebring het en die verwysings na "Afrikaanse kultuur" en "die tradiesies van ons ou volk" (Anon., 1936:7).

\subsection{Kultuurgeskiedenis as werkersgeskiedenis}

Soos uit die aankondiging afgelei kan word, was die aard van dié identiteit op daardie stadium tengwaarts, op die verlede, gerig. Die gehoor moes die voorstelling van die handeling ervaar as 'n teruggryping na 'n tyd toe dit met die voorsate van die klerewerkers beter gegaan het as toe. Die opvoering moes vir die gehoor die onverskrokkenheid en onoorwinbaarheid van gees van hul voorsate tydens die Anglo-Boereoorlog versinnebeeld. Verder moes Sannie Pienaar die beeld voorhou van 'n persoon wat die deugde van die tyd nagevolg het, naamlik getrouheid in haar huwelik, iemand wat ondersteunend en hardwerkend is in die huis, en wat gewillig is om ter wille van haar oortuigings en haar mense op te offer.

Hierdie voorstelling het aangesluit by die konstruksie van die ideologie van die volksmoeder, wat 'n doelbewuste poging was om blanke Afrikaanssprekendes onder die mitologiserende vaandel van Afrikanerskap te verenig (Brink 1990; Van Niekerk 1996). Ideologiese konstruksies soortgelyk aan dié van die volksmoeder kom in KWU-tekste soos Drie spioene (ArKW 42.2.7) en Hester Cornelius (1942a; 1942b) se Die offerande voor. In Die offerande stem Lettie se optrede met Sannie s'n (in Horak se drama) ooreen aangesien albei, nieteenstaande die uiteenlopende aard daarvan, gewillig is om 'n offer te bring. Lettie is aanvanklik gewillig om haar liefde vir Danie ter wille van die behoud van die plaas op te offer, maar verander later van mening; Sannie offer Willie ter wille van haar vaderlandsliefde op.

\subsection{Outobiografiese fiksionalisering}

Deur sekere deugde uit die verlede op hul eie situasie van toepassing te maak en in hul werkersklasdramas op te neem, het die KWU-dramaturge hul kultuurgeskiedenis op die wyse van die outobiografie gefiksionaliseer. Met verwysing na Die offerande het hulle spesifieke kultuurwaardes uit die verlede op hul hede van toepassing gemaak. Daardeur was dié dramaturge met 'n proses van selfdefinisie besig, wat, soos Gready (1994) ten opsigte van werkersklasdramas uit KwaZuluNatal (KZN) aantoon, eensydig was. Soos in die KZN-tekste vind ons in die KWU-tekste die oortuiging "that "our picture' was the "true picture" (Gready, 1994:166), wat daarop afgestem was om die eenheid en solidariteit van 'n werkersklasbestaan en -identiteit vas te lê. 
In KWU-dramas blyk hierdie oortuiging veral uit die voorstelling van die personasies en die aanbieding van die slot. Die karakterisering is meestal eendimensioneel en personasies is of lid van die werkersklas of van die baasklas. Personasies verteenwoordig stereotipes soos die verontregte werker en die dikwels militante segspersoon of moederlike verteenwoordiger van die KWU. Hulle word teengestaan deur karikature of gedemoniseerde verteenwoordigers van die "stelsel", naamlik toesighouers, brandsiek (die KWU se woord vir die Engelse woord, "scab"), polisiemanne, hofaanklaers of selfs 'n magistraat.

Kenmerkend van die KWU-dramas is die voorkoms van 'n ideologiese sluitstuk, waardeur die slotgedeelte duidelik bo die res van die handelingsverloop uitstaan. Dié sluiting is feitlik sonder uitsondering emosioneel, opruiend en daarop gemik om reaksie van die gehoor te ontlok. Daarvan vorm die sing van "Die rooivlag" of die "Die internasionale" deur die akteurs 'n belangrike deel - vergelyk onder andere in Broers (ArKW 42.2.6), Drie spioene (ArKW 42.2.7) of Eendrag (ArKW 54). In Drie spioene, byvoorbeeld, wil die toesighouer Kelly vir Sannie ontslaan omdat sy die oggend nie kom werk het nie omdat sy haar moeder begrawe het. Die drie spioene, of vakbondverteenwoordigers, verhoed hom om dit te doen en beveel 'n staking. Die Grootbaas verskyn en wil hul wegjaag, maar aangevuur deur hul nuutgevonde solidariteit daag die werkers hom uit deur die sing van "Die rooivlag". Die KWUniewag, 'n groep KWU-lede geklee in 'n militêre tipe uniform, wat soms by geleenthede moes help om die orde te handhaaf, verskyn dan op die verhoog. Die verskyning van die Uniewag hou geen verband met die voorafgaande gebeure nie, maar moes deur die gesag wat hul teenwoordigheid afgedwing het, by die gehoor die oortuiging versterk. "that 'our picture' was the 'true picture"' (Gready 1994:166).

Dat die gehoor aan die sing van "Die rooivlag" meegedoen het, is meer as 'n waarskynlikheid. Tewens, die klerewerkers het dikwels van sang gebruik gemaak om hulself in 'n tyd van nood te onderskraag. So verhaal Johanna Cornelius (1936) hoe lede van die KWU tydens die 1932-staking onder andere "Die rooivlag" in Germiston se tronk gesing het. Daardeur sluit KWU-dramas aan by die sang-en-respons-tegnieke wat in die $\mathrm{KZN}$-werkersklastekste uit die tagtigerjare voorgekom het en wat daarop gemik was om gehoordeelname te verkry. "You also need songs," verklaar Sitas (1986:103), "to create a mood, to pass on information related only to the play whilst at the same time using the most identifiable song forms." As gevolg van hierdie mate van gehoordeelname het hul dramaopvoerings vir die KWU gunstige geleenthede vir die skep en vestiging van werkersolidariteit en -identiteit gebied.

Die vestiging, vaslegging en "outobiografisering" het van die begin af ' $n$ aantal weersprekings ingehou (my toepassing vervolgens in navolging van Sitas, 1986). In soverre hul "outobiografisering" die verlede betrek het, hou belangrike 
weersprekings met die aard van die voorgestelde geskiedenis verband. Ten opsigte daarvan het KWU-dramaturge in dramas soos Die offerande of Slavin van Suid-Afrika hul inspirasie onder andere in die Afrikaner se verlede gevind. Daarmee het hulle van dieselfde bron gebruik gemaak as die aanhangers van 'n opkomende Afrikanernasionalisme, soos dit in hoofstroomtekste voorgekom het (vergelyk Hofmeyr, 1993).

Dié vorm van "outobiografisering" verteenwoordig 'n vorm van manipulering van sosiale prosesse deur KWU-dramaturge, waardeur die teenstelling tussen die mitologisering van die verlede en die realisme van die hede eerder uitgelig as versluier is (vergelyk Sitas, 1986:99-100, 102-103). Juis die teenstelling tussen hede en verlede moes doelbewus die waameming verskerp dat die verlede vir werkers ' $n$ beter bestel verteenwoordig het en terselfdertyd die persepsie van verontregting in die hede versterk. Deur van eendimensionele personasies (dikwels die werkers self of hul segspersone in die spel) en stereotipes of karikature (die baasklas of hul verteenwoordigers) gebruik te maak, het KWUdramaturge simplistiese teenstellings geskep wat inderwaarheid 'n driedubbele botsing van moontlike wêrelde (Elam, 1980:98-134) verteenwoordig het. 'n Voorbeeld daarvan kom in Hester en Johanna Comelius (ArKW 57) se Slavin van Suid-Afrika voor.

In ses "bedrywe" (tonele) word in die drama 'n beeld geskep van die huislike en werkslewe van werkersklasvroue. In die tweede bedryf kom drie jong vroue na werk honger tuis. Hulle besluit om die volgende dag hul eise te stel, naamlik "grond [...] en alles wat ons toekom". Die werker Anna, formuleer hul eise dan soos volg:

Kom ons volg die voetstappe van die Voortrekkervrou wat gesê het "Al moet ons blootvoets oor die Drakensberge loop sal ons nie terug gaan na die land verdrukking nie!' Medewerkers kom ons organiseer 'n optog van vrouens en kinders deur die strate van ons stad en ons eis 'n beter lewe vir elke man, vrou en kind! Maak 'n end aan hierdie ellende. Laat die vrou van Suid-Afrika die volgende eis: Grond vir die arme plaasboer. Hoër lone en beter kondisies, vir die werker in die fabrieke, myne, winkels, paaie, en oral waar ons werk. Ordentlike huise vir almal om in te woon, nie net alleen vir die klomp in Parktown nie. Nie meer wil ons meer as die helfte van ons lone betaal aan huishuur nie. Moeg is ons om kindertjies te sien ondervoed en uitgehonger. Ons eis melk, vleis, groente en brood vir ons en ons toekomstige volk. [Oorspronklike onderstreping.]

Anna se eise vertrek elke keer van die hede as dramatiese moontlike wêreld. Haar verwysings na grond, lone, behuising en ondervoede en uitgehongerde kinders verteenwoordig inderdaad wat Sitas (1986:94) "metaphors of conceits to illuminate this reality" sou noem. Haar verwysing na "die Voortrekkervrou", dit wil sê die verlede as moontlike wêreld, is bedoel as 'n oproep om haar gehoor in 
die hede te mobiliseer. Dieselfde geld ten opsigte van haar verwysing na die toekoms as moontlike wêreld, met ander woorde na "ons toekomstige volk".

KWU-werkersklasdramas en die kultuurterrein het gevolglik deel geword van 'n stryd om die besit van die hart van die klerewerkers. Hierdie aspek van hul werkersgeskiedenis het, soos uit Anna se eise in Slavin van Suid-Afrika (ArKW 57) blyk, meestal 'n ekonomiese agtergrond gehad.

\subsection{Ekonomiese agtergrond as werkersgeskiedenis}

Hofmeyer (1980:25) wys daarop dat die verhuising van Afrikaanssprekendes na die stede toe reeds voor die Anglo-Boereoorlog begin het. Teen 1894 was Fordsburg en Jeppestown reeds as oorwegend Afrikaanse buurte bekend. Dié beweging was die gevolg van 'n ekonomiese stoot-en-trek-aksie: enersyds het hoë grondpryse verarmde bywoners gedwing om 'n heenkome in die stad te soek; andersyds het die vooruitsig op werkgeleenthede op die myne hulle en ander Suid-Afrikaners daarheen aangetrek. Na die oorlog het die stroom toegeneem, maar is die situasie vererger deur die werkersklas se postkoloniale onderhorigheid aan die nuwe, meestal Engelssprekende, baasklas. KWU-dramaturge het dié situasie van onderhorigheid in hul tekste, daarin verteenwoordig deur die optrede van toesighouers en fabrieksbase, as 'n bedreiging van die werkers deur kapitalisme voorgestel.

Voorbeelde is die toesighouer Kelly in Drie spioene (ArKW 42.2.7), bygestaan deur die setleiermeisie, Susie, of kaptein Mitchell, Hans de Wet se hoof in Broers (ArKW 42.2.6). In Drie spioene beskuldig Anna vir Susie daarvan dat sy, 'n Afrikaanssprekende, onnodig aan Engels voorkeur gee. Waarskynlik die duidelikste voorbeeld is die voormeisie mej. Hart, haar toesighouer Levine en die fabrieksbaas Brown in Eendrag (ArKW 54). Brown praat hoofsaaklik Engels met die werkers, waardeur dié taal gemerk word as die taal van die elite. Die gebruik van Engels en die optrede van die baasklas in die werkplek veroorsaak weersin en lei in die drama daartoe dat die werkerspersonasies hul woon- en werksituasie met dié van die baasklas vergelyk.

Daar kom in klerewerkerstekste verskeie voorstellings van werkers se ervaring van die gevolge van hierdie onderhorigheid voor, in die vorm van fisiese mishandeling in die werkplek of beskrywings van haglike armoede en swak woonomstandighede. Fisiese mishandeling en verskillende vorme van uitbuiting onder andere prostitusie en seksuele teistering - het algemeen in klerefabrieke van die tyd voorgekom (Brink, 1986:66, 99, 157). 'n Voorbeeld is Kelly se woorde en optrede aan die begin van die derde bedryf van Drie spioene (ArKW 42.2.7): 
(Skreeu baie hard van waar hy staan) 'Shut up, daar! Sal jy jou smoel hou? Of moet ek jou uit die fabriek uitskop? (Hy stap nader na die meisie, terwyl hy aanhou praat) Jy dink seker jy word betaal om hier te sit en babbel, nè? (Hy gee haar 'n harde klap teen haar kop) Ek het nog nooit jou tong gesien stil staan nie. ([...] Kelly stap weg, brom-brom. $\mathrm{Na}$ 'n rukkie stap Kelly die vertrek uit.)'

Dit is moontlik om werkers se ervaring van die gevolge van die verhuising na die stad as bestaansruimte en van die fabriek as werkplek, as 'n botsing van morele ordes te beskou. Sitas (1986:97) beskryf die verskyningsvorme daarvan as "new forms of worker association [that] involves novel codes of conduct and expectations", wat in werkersklasdramas uit KwaZulu-Natal aanleiding gegee het tot "forms of individualist escapism, drinking habits and forms of violence". Hy (Sitas, 1986:97) tipeer die personasies in die KZN-tekste soos volg:

After all, it is these 'escape mechanisms' of township life, the so-called 'vibrancy' of the ghetto that has created some of the most interesting theatrical characters. [...] They are characters that are morally ambiguous and flamboyant, storing wisdom and a sense of self-preservation however much their life is degraded. They are resolute survivors, 'off-beat', half tsotsi and half drunkard.

Alhoewel 'n soortgelyke botsing van morele ordes in die klerewerkers se bestaan uitgewys kan word, kom slegs geringe raakpunte tussen die voorstellings van personasies in KWU- en KZN-tekste voor. Hiervan is die inleiding tot Anna se eise (aangehaal bo) in Slavin van Suid-Afrika (ArKW 57) 'n voorbeeld:

Ons vrouens is die slawe van ons land en die stelsel waaronder ons gebuk gaan. Dis hoog tyd dat ons hierdie juk van verdrukking afgooi. Die mans wat die wette vir ons land maak het ons volk so verdeel met hulle politieke gekonkel dat ons vrouens en kinders vandag van ellende en honger moet omkom.

Die implikasie is dat die lede van die KWU 'n nuwe morele orde vir die land sal skep. Verder is die feministiese inslag van Anna se woorde verklaarbaar teen die agtergrond daarvan dat die KWU se ledetal oorheersend vroulik was. Waar manlike karakters in tekste wel as "half drunkard" voorgestel word, word hul deur die optrede van 'n sterk vroulike karakter tot insig gebring. 'n Voorbeeld is Jim wat, in The trial of the 22 (ArKW 42.2.5), as gevolg van die toedoen van sy vrou Mary, ophou drink en hom by die saak van die KWU skaar. Hierdie gelykmatigheid van karakterisering in KWU-dramas is waarskynlik verklaarbaar vanuit die Unie se bestuur se aandrang op 'n fatsoenlikheid wat nie ruimte gelaat het vir "resolute survivors, 'off-beat', half tsotsi and half drunkard" (Sitas, 1986:97) nie. 


\subsection{Politieke geskiedenis as werkersgeskiedenis}

Naas die ekonomiese agtergrond, het KWU-dramas as die voorstelling van 'n werkersklasgeskiedenis, teen 'n bepaalde politieke agtergrond afgespeel. Politieke invloede het, soos die geval was met die werkersklastekste uit die tagtigerjare in KwaZulu-Natal, van binne en buite op KWU-dramaturge ingewerk. Ten opsigte van 'n beoordeling van KWU-werkersklasdramas geld dus Gready (1994:168) se opmerking dat " $[t]$ he apparent clarity of the theatre movement's [GWU's] self-definition privileged, masked and silenced a number of issues relating to the way in which worker culture contextualised itself culturally and politically".

Van besondere belang vir 'n evaluering van hierdie agtergrond, was die opkoms van Afrikanernasionalisme, soos dit verband gehou het met die groei van die Nasionale Party. In die tydperk onder bespreking het die Nasionale Party probeer om sy invloed in die bestaande Afrikaanse vakbonde uit te brei. Van die metodes wat gebruik is, was veldtogte in koerante waartydens die KWU gediskrediteer is, aanslae van Nasionale Party-aktiviste om van buite 'n houvas op die KWU te verkry of pogings om die KWU se deelname aan die herdenking van die Groot Trek in 1938 te verhoed. Vanuit die KWU se perspektief was daar selfs aanslae op hul integriteit deur predikante van die N.G. Kerk (vergelyk Witz 1984, hoofstuk 5: "The Christian-National Assaults on the G.W.U.")

Opskrifte in nommers van die Klerewerker bied 'n aanduiding van die aard van die Nasionaliste se aanslag. Die KWU is byvoorbeeld daarvan beskuldig dat hulle aanhangers is van kommunisme (vergelyk L. de H. Larkins se brief, "Wat dink U? Ons lesers se opinies. Mnr. Kok en sy rooi spook", in die Klerewerker, Oktober 1938), terwyl die Nasionaliste ook die rassesnaar teen hulle geslaan het (vergelyk Korrespondent se reaksie, "Germiston werksters dans nie met kaffers nie", in die Klerewerker, Julie 1937). Tog het die KWU hom nooit van sy Afrikaneragtergrond losgemaak nie.

Daarvan getuig die KWU se deelname aan vieringe ter herdenking van die Groot Trek in 1938. Selfs hierdie deelname was nie sonder kontroversie nie. Die reëlingskomitee wat in Germiston verantwoordelik was vir die herdenking, het, volgens 'n berig in die Klerewerker (Anon., 1938:5), "opdrag gekry om die amptenare van die Klerewerkersunie te versoek om hulle [die KWU se] Kommando terug te trek [omdat die KWU] hierdie kommando georganiseer het om die Eeufeesviering kwaad aan te doen". Dit wil egter voorkom of die komitee (bestaande uit vier predikante, naamlik di. S. de Villiers, J.P. Gertenbach, J.H. Boneschans en J.C. du Plessis) se versoek minder gemotiveer is deur hul kommer oor die verloop van die vieringe, as deur hul afkeur van die klerewerkers se steun vir die "sosialistiese beweging[s] [...] wat nie met die bewerende nasionalisme van dr. Malan en Kie." verwar moet word nie (Anon., 1939a:12). 
Dit is opvallend dat die Nasionale Party se aanslag op die KWU in 'n hoë mate op die Unie se struktuur gerig was. 'n Kulminasie van dié strukturele aanslag kon eers plaasvind nadat die party in 1948 aan bewind gekom en die Wet op die Onderdrukking van Kommunisme in 1950 deurgevoer is. 'n Gevolg van dié gebruik van regeringsmag was dat Solly Sachs, die algemene sekretaris van die KWU, in 1953 gedwing is om die land te verlaat en hom in Engeland gaan vestig het (Sachs, 1957:196-207).

Daar was egter nie, soos in die geval van swart versetdramas vanaf die middel van die vyftigerjare, 'n direkte poging van die Nasionale Party-regering om die KWU-dramastem stil te maak nie. Dit was ook nie nodig nie, omdat die Afrikaner se ekonomiese ruimte vanaf 1948 toenemend verbeter het, waardeur die blanke lede van die KWU onder die invloed van die regerende party gekom en nie meer werkgeleenthede in die klerebedryf gevind het nie, maar in die staatsdiens (vergelyk die bespreking bo van Hester Cornelius se Tant Mieta, die Cruet Stand en die Klerewerkersunie van S.A., ArKW 56).

\section{Samevatting}

Neem 'n mens dus die kulturele, ekonomiese en politieke agtergrond van die KWU-werkersklasdramas in ag, blyk dit dat hierdie tekste, soos die KZN-tekste oor die algemeen, deur weersprekings gekenmerk is. Enersyds is hulle as werkersklasdramas "a self-consciously collective and ideological form of autobiographical expression"; andersyds is hulle 'n "transaction on many levels between cultural practices and forms, languages, races, classes, agendas and so on" (Gready, 1994:166-167). Soos in ander werkersklastekste (vergelyk Gready, 1994:183-185) het kulturele aktiviste in die KWU self die aard van die betrokke weersprekings (vergelyk Sitas, 1986) beïnvloed. In hierdie verband is die KWUtekste deur 'n klein groepie dramaturge geskep, wat ook as aktiviste deel was van die KWU se bestuur (vergelyk Sachs, 1957:40-43). Die aktiviste-susters en KWU-bestuurslede Johanna en Hester Cornelius, het die grootste bydrae op dramagebied gelewer.

Dit is van belang dat die KWU-dramaturge sonder die bemiddeling van kultuurwerkers van buite (vergelyk Von Kotze, 1988), met ander woorde vanuit KWU-geledere self, gekom het. Dit het aan KWU-dramas 'n kulturele eiesoortigheid gegee wat veroorsaak het dat die weersprekings in hul dramas verskil het van wat in die KZN-opvoerings voorgekom het. (Vergelyk byvoorbeeld die afwesigheid van die invloed van tradisionele Afrika-oraliteit.) Andersyds is 'n ooreenkoms dat die antikapitalistiese en pro-werkerrigtings wat in KWU-dramas voorgestaan is, deur aktiviste van binne die unie, wat Gready (1994:181) die "ghosts in the autobiographical machine" noem, gedryf is. Dit was 'n interne, 
spesifiek Afrikaans aandrywing wat as 'n proses onder andere by die beplande opvoering van I.G. Horak (1925) se drama Sannie Pienaar begin het.

Gemotiveer deur die geestelike pyn wat hul kulturele, politieke en ekonomiese agtergrond aan hul opgedring het, het KWU-dramaturge vorm gegee aan 'n alternatiewe Afrikaanse teater. Daardeur is hul dramatekste 'n polifoniese tapisserie van herinnering aan 'n Afrikaanse werkersklasbestaan waaraan geen waarheids- en versoeningskommissie nog aandag gegee het nie.

\section{Verwysings}

Anon 1936 Om die koffie tafel. Klerewerker: 7, November

Anon. 1938. Onthou, die klerewerksters is ook afstammelinge van die Voortrekkers! Klerewerker: 5 , Oktober.

Anon 1939a. Afrikaner Nasionalisme en die arbeiderbeweging Klerewerker. 12, Mei.

Anon. 1939b. Hou op met die oorlogsbasuin! Klerewerker: 8-9, Desember.

Anon. 1940. Kan u sing, dans, toneel speel enige musiek instrument speel? Klerewerker: 12, April/Mei

Anon. 1941a. Werkers van Germiston gebruik julle talente! Klerewerker. 12, Maart/April.

Anon. 194lb Aankondiging van opvoering van Die offerande. Klerewerker. 8, September/ Oktober.

Anon. 1941c. The People's Theatre Klerewerker. 11, September/Oktober.

Anon. 1941d. Kersfees vir die armes. Klerewerker: 5-6, November/Desember.

Anon. 1947. Die plig van 'n fabriek verteenwoordiger. Klerewerker. 1-4, Mei/Junie.

Brink, Elsabé. 1984. Plays, poetry and productions: the literature of the Garment Workers. South African Labour Bulletin, 9(8):32-51.

Brink, Elsabé. 1986. The Afrikaner women of the Garment Workers' Union, 1918-1939. Johannesburg : University of the Witwatersrand. (M.A. dissertation )

Brink, Elsabe 1989. Purposeful plays, prose and poems. the writings of the Garment Workers, 1929-1945. In: Clayton, Cherry. (ed.) Women and writing in South Africa: a critical anthology. Marshalitown : Heinemann. p. 107-127.

Brink, Elsabé. 1990. Man-made women: gender, class and the ideology of the volksmoeder In: Walker, Cherryl. (ed ) Women and gender in Southern Africa to 1945. Cape Town : David Philip p. 273-292.

Britz, Minnie 1941. Kaapstad ontwaak Klerewerker: 9, Julie/Augustus

Cornelius, H[ester]. 1941. Eendrag teater. Klerewerker: 11, Mei/Junie.

Cornelius, Hester 1942a Die offerande [eerste bedryf]. Klerewerker: 3-6, Julie/Augustus.

Cornelius, Hester. 1942b. Die offerande [tweede tot vyfde bedryf]. Klerewerker: 3-6, November/Desember

Cornelius, Johanna 1936. In Germiston se tronk in 1932. Klerewerker: bladsy onvermeld, Oktober

Elam, Keir. 1980. The semiotics of theatre and drama. London : Methuen

Gready, Paul. 1994 Political autobiography in search of liberation: working class theatre, collaboration and the construction of identity. In: Gunner, Liz (ed.) Politics and performance: theatre, poetry and song in Southern Africa. Johannesburg : Witwatersrand University Press p 162-190.

Hofmeyer [Hofmeyr], lsabel 1980 Perspectives on working-class life among black and Afrikaans writers, 1890-1930 Africa Perspective, 16:22-41 
Hofmeyr, Isabel. 1993. Building a nation from words: Afrikaans language, literature and ethnic identity. In: Marks, Shula \& Trapido, Stanley. (eds.) The politics of race, class and nationalism in twentieth-century South Africa. London : Longman. p. 95-123.

Horak, I.G. 1925. Sannie Pienaar: 'n drama uit die Twede Vryheidsoorlog (Op waarheid gegrond). Kaapstad : Nasionale Pers.

Jacobson, Marcelle \& Cunningham, Anna M (comps.) 1980. Records of the Garment Workers' Union. Johannesburg : The Library, University of the Witwatersrand. (Historical and literary papers: inventories of collections, volume 9.)

Korrespondent. 1937. Germiston werksters dans nie met kaffers nie. Klerewerker. 6, Julie.

Larkins, L. de H. 1938. Wat dink U? Ons lesers se opinies. Mnr. Kok en sy rooi spook. Klerewerker: 9, Oktober.

Lourens, Amanda. 1997. Afwesig uit die kanon: die prosageskrifte van die klerewerkers. Tydskrif vir Nederlands en Afrikaans, 4(2) 1-28.

By: http://www. sun ac za/afrndl/tna/972/index html, op 26/05/98.

Louw, N.P. van Wyk. 1939. Die rigting van die Afrikaanse letterkunde. In: Louw, N.P van Wyk Berigte te velde: opstelle oor die idee van 'n Afrikaanse nasionale letterkunde. Pretoria : Van Schaik. p. 9-18

McPherson, Jessie. 1941 Ons vrouens van 'Werkende Vrouens Federasie'. Klerewerker. 2-3, Maart/April

Myburgh, Mary \& Goldwyer, Maud. 1939. 'n Staaltjie uit die lewe van twee klerewerkers. Klerewerker: 3, 6-8, Augustus.

Sachs, E.S. (Solly). 1957. Rebels daughters. London : MacGibbon.

Sitas, Ari 1986. Culture and production: the contradictions of working class theatre in South Africa. Africa Perspective (New Series), 1(1-2):84-110.

Stander, Christell \& Willemse, Hein. 1992. Winding through nationalism, patriarchy, privilege and concern: a selected overview of Afrikaans women writers Research in African Literatures, 23(3):5-24.

Van Coller, H P. 1995. Die Afrikaanse plaasroman as ideologiese refleksie van die politieke en sosiale werklikheid in Suid-Afrika. Stilet, 7(2):22-31.

Van Niekerk, Marlene 1996. Afrikaner woman and her "prison": Afrikaner nationalism and literature. In: Kriger, Robert \& Kriger, Ethel. (eds.) Afrikaans literature: recollection, redefinition, restitution. Papers presented at the 7 th Conference on South African literature at the Protestant Academy, Bad Boll. Amsterdam: Rodopi. p. 141-154.

Van Wyk, Johan. 1995. Constructs of identity and difference in South African literature Durban : CSSALL.

Van Wyk, Johan. 1997. "Volcano needing constant watching": South African white labour and socialist culture 1900-1924. Paper presented at the 15th Congress of the International Comparative Literature Association, University of Leiden, The Netherlands, 16-21 August.

Von Kotze, Astrid 1988. Organise \& act. Culture and Working Life : Durban, Department of Industrial Sociology, University of Natal

Witz, Leslie. 1984. Servant of the workers: Solly Sachs and the Garment Workers' Union, 1928-1952. Johannesburg : University of the Witwatersrand. (M A dissertation.)

Witz, Leslie 1988. Separation from unity: the Garment Workers Union and the South African Clothing Workers Union 1928 to 1936. Social Dynamics, 14(1):34-45

\section{Lys van argivale bronne}

ArKW 42.2.2. Bure moeillkhede. (William Cullen-lêer: AH1092/Cba2 4.2.)

ArKW 42.2.3. Labour beats the drum (William Cullen-lêer: AH1092/Cba 2.42.) 
ArKW 42.5 The trial of the 22: a one act play in three scenes. (William Cullen-lêer: AH 1092/Cba 2.4.2.)

ArKW 42.2.6. Broers. (William Cullen-lêer: AH1092/Cba2.4.2.)

ArKW 42.2.7. Cornelius, Johanna. Drie spioene. (William Cullen-lêer: AH1092/Cba2.4.2.)

ArKW 48. Labour beats the drum. (Beskikbaar gestel deur Elsabé Brink.)

ArKW 49. The trial of the 22: a one-act play in three scenes. (Beskikbaar gestel deur Elsabé Brink.)

ArKW 54. Cornelius, Hester: Eendrag. (Beskikbaar gestel deur Elsabé Brink.)

ArKW 56. Tant Mieta, die Cruet Stand en die Klerewerkersunie van S.A. (Beskikbaar gestel deur Elsabé Brink.)

ArKW 57. Cornelius, Hester \& Cornelius, Johanna Slavin van Suid-Afrika. (Beskikbaar gestel deur Elsabé Brink.) 
